\title{
Modelling of Compartmentalized Household Storm water Detention System using SWMM5
}

\author{
Darrien Yau Seng Mah ${ }^{1}$, Johnny Ong King Ngu ${ }^{2}$, Siti Noor Linda bt Taib ${ }^{3}$, Md Abdul Mannan ${ }^{4}$ \\ ${ }^{1}$ Faculty of Engineering, Universiti Malaysia Sarawak, Malaysia, ysmah @ unimas.my \\ ${ }^{2}$ Faculty of Engineering, Universiti Sarawak Malaysia, Malaysia, johnnyngu91@gmail.com \\ ${ }^{3}$ Faculty of Engineering, Universiti Malaysia Sarawak, Malaysia, tlinda@unimas.my \\ ${ }^{4}$ Faculty of Engineering, Universiti Malaysia Sarawak, Malaysia, mannan@unimas.my
}

\begin{abstract}
This paper describes the modelling efforts of compartmentalized stormwater detention system. Such a system consists of multiple modular units that creates compartments to hold stormwater. Particular attention is paid to a specific R\&D product named StormPav Green Pavement System. US EPA's SWMM5 is utilized as the tool to explore two of its functions, namely the storage unit and conduit to model flow through a StormPav system. The first model assumes the compartmentalized characteristics of StormPav could be represented by applying the effective storage volume in a storage unit; while the second model, using a conduit. A StormPav field test is constructed, and the data collected are used to validate the two models. The outcomes show that model with storage unit is better representing the compartmentalized stormwater detention system.
\end{abstract}

Key words : Inflow, Outflow, StormPav, Water level.

\section{INTRODUCTION}

Stormwater detention system is manmade structure to hold and store stormwater. Concrete is one of the materials used to manufacture these structures. Precast concrete products could be molded into various shapes and forms that allow compartments to be provided for stormwater detention [1-2]. Two examples of such a product are presented in Figure 1.

The first product, MC2 Multi-Cell [3] is a rectangular concrete vault, in which a series of compartments are created within the vault with orifice tube connecting the compartments. This product achieves the purposes of stormwater detention by filling the compartments slowly with the restriction of orifice tubes. Each vault is also a modular unit that allows multiple units to be combined.

On the other hand, RainVault ${ }^{\circledR}$ [4] is made up of hollow circular precast concrete pieces. The inner diameter of each hollow circular piece provides compartment to hold stormwater. These circular pieces could be joined to form a long vault according to the requirement of a project site, in which both ends are capped.

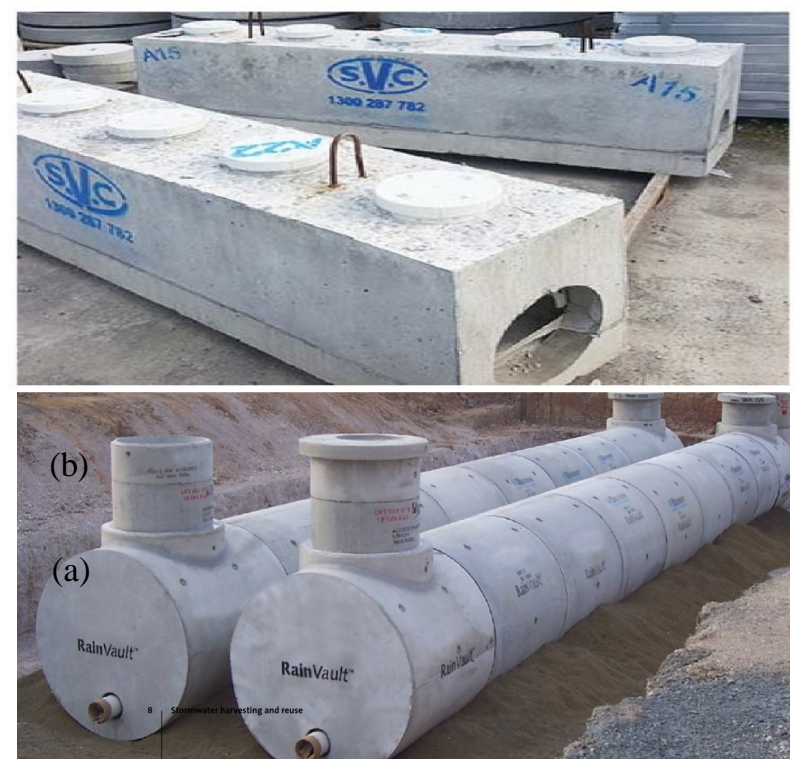

Figure 1: Examples of Precast Concrete Stormwater Detention System, a) MC2 Multi-Cell (http://www.svc.com.au) and b) RainVault ${ }^{\circledR}$ (http://humeswatersolutions.com.au)

Unlike the above-mentioned precast concrete products, StormPav Green Pavement System [5], or in short StormPav in Figure 2, is a developing R\&D stormwater detention product that is not yet fully commercialized.

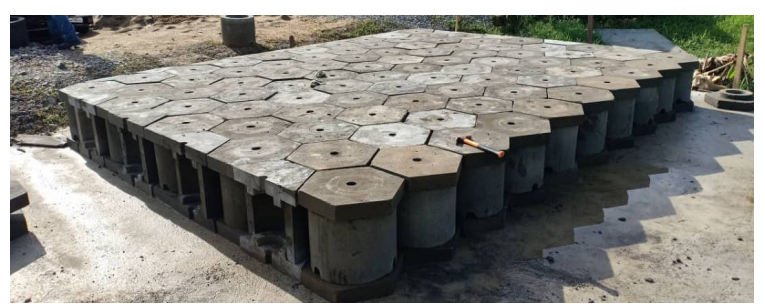




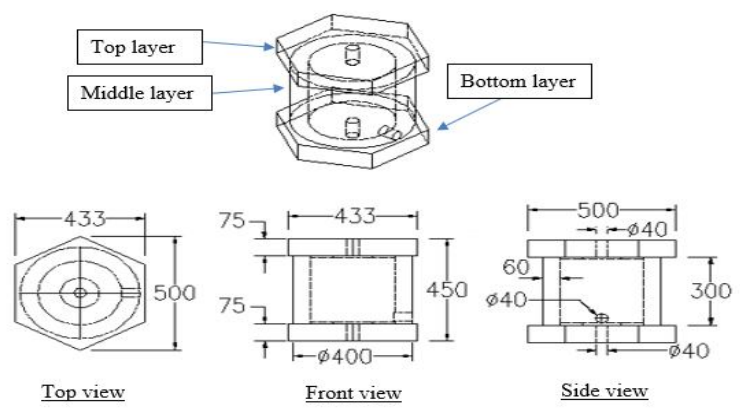

Figure 2: StormPav Green Pavement System

A single modular unit of StormPav is made up of three precast concrete pieces, namely two hexagonal plates and one hollow cylinder piece. The hexagonal plates form the top layer for supporting loads and the bottom layer for foundation. The hollow cylinder pieces form the middle layer that are arranged in such a way creating compartments within and without the cylinders.

One of the tasks of this R\&D team is to model the StormPav system. US EPA's Storm Water Management Model version 5.0 (SWMM5) is chosen as the software has a longstanding history to represent hydrological and hydraulic characteristics of urban drainage systems [6].

SWMM5 is not formulated to model compartmentalized system. Therefore, some explorations are needed. Previous studies [7-8] has been using the "storage unit" in SWMM5 to represent StormPav system, by taking only the effective storage volume. External calculation is carried out by deducting the concrete volume from the gross storage volume.

There are also other studies [9-11] that represent StormPav system using the "conduit" in SWMM5. Authors reported that StormPav could convey water via its middle layer and a closed rectangular "conduit" is best to represent the system. The developed SWMM5 model is compared with simulations of SolidWorks Flow Simulation and InfoWorks Collection System models. The results are found matched.

\section{FIELD TEST}

These past studies [7-11] have been verified numerically based on water balance; however, these studies have not been validated due to the absent of a StormPav system in the field. As such, the R\&D team has set up an actual-scaled StormPav system in a residential setting in Figure 3.

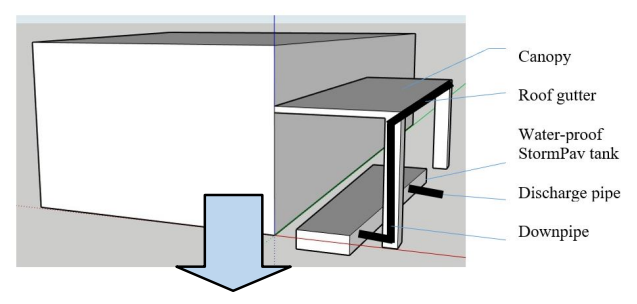

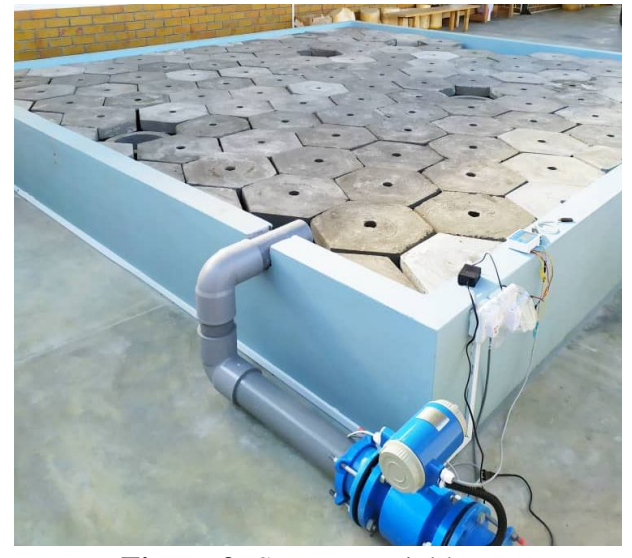

Figure 3: StormPav Field Test

The StormPav system is taking a surface area of $20 \mathrm{~m}^{2}(4.63$ $\mathrm{m} \times 4.33 \mathrm{~m}$ ) and a depth of $4.5 \mathrm{~m}$. The surface area could be fitted with two cars atop and it is meant to be installed under a residential car porch.

For the purposes of the field test, a voluntary property owner has allowed the use of the house's $95 \mathrm{~m}^{2}$ side canopy and $3 \mathrm{~m}$ height $0.1 \mathrm{~m}$ diameter down pipe to be connected to the StormPav system under the canopy. The outlet is $0.05 \mathrm{~m}$ circular pipe.

Two flowmeters are installed, each at the down pipe and outlet pipe respectively. Two water level sensors are installed, each at either side of the StormPav system. A rainfall gauge is installed at the property lot as well.

\section{METHODS}

With the availability of field data from the rain gauge, flowmeters and water level sensors, validation of SWMM5 representation of StormPav system could be carried out. A flow of model building is presented in Figure 4.

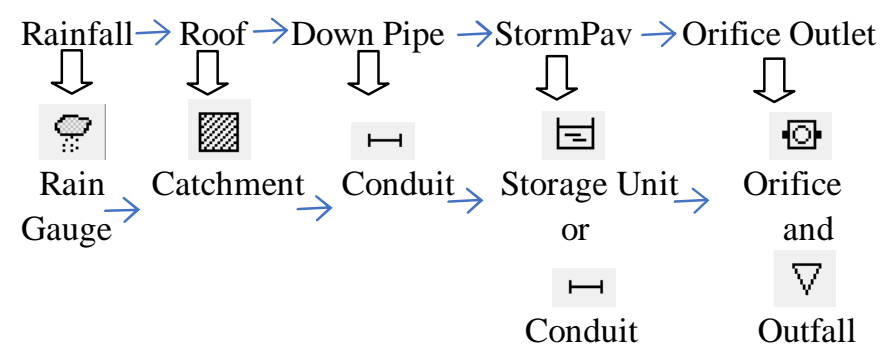

Figure 4: SWMM5 Model Building

Drainage modelling starts with the rainfall. As rainfall lands on the residential roof, runoff is generated and flowed to the roof gutter and down pipe. Water enters the StormPav system through the down pipe and leaves via an outlet. Eventually, the water reaches a final discharge point or an outfall. 
Darrien Yau Seng Mah et al., International Journal of Emerging Trends in Engineering Research, 8(2), February 2020,344 - 349

Three historical storm events are selected with each peak rainfall depth close to $30 \mathrm{~mm}$ which is in equivalent to 10-minute, 10-year Average Recurrent Interval (ARI) design rainfall of local weather:

a) 5-hour storm event on 7 December 2019;

b) 7-hour storm event on 1 December 2019; and

c) 8-hour storm event on 8\&9 December 2019.

The corresponding inflow data from down pipe flowmeter, outflow data from the outlet pipe, and water level data from the sensor are compared with the results from SWMM5. These data are presented in the Appendices. Two scenarios to represent StormPav system following the past studies are created, namely:

a) Model 1 (M1), using "storage unit" in SWMM5; and b) Model 2 (M2), using "conduit" in SWMM5.

\section{RESULTS AND DISCUSSION}

Comparison of field and modelled hydrographs associated with 7 December 2019 storm event is presented in Figure 5.

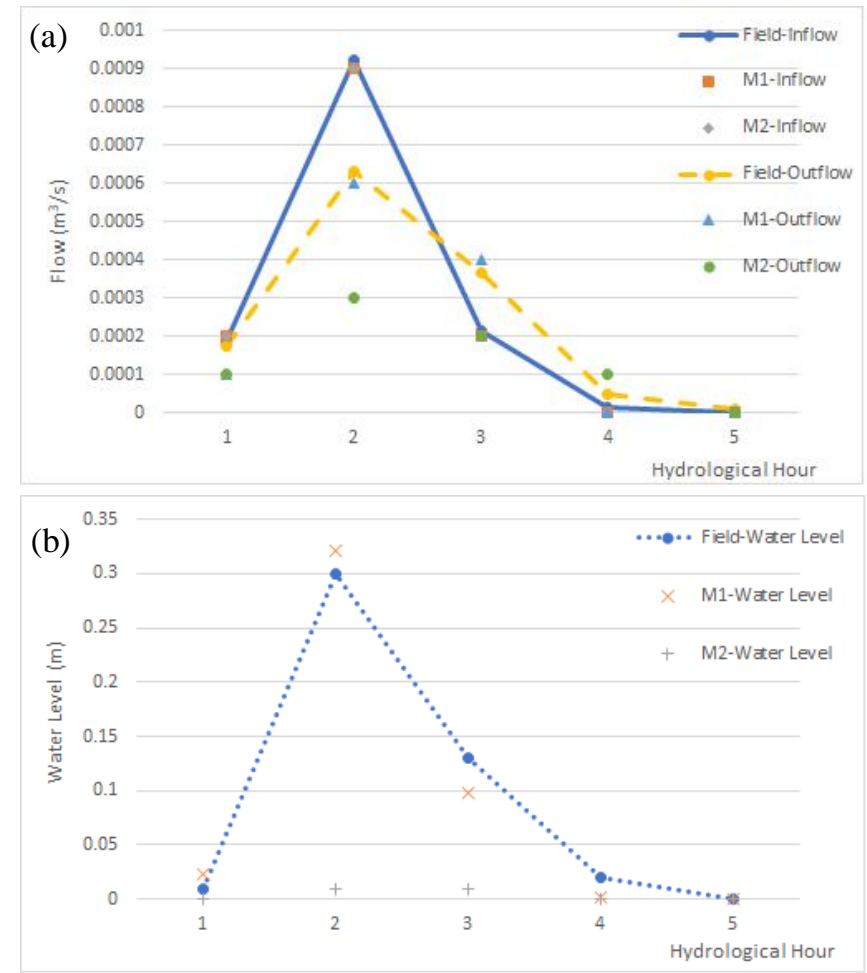

Figure 5: Simulation of StormPav System Subjected to 7 December 2019 Storm Event, a) Inflow and Outflow and b) Water Level Hydrographs

The 5-hour plot is first compared between Field-M1 arrays, followed by Field-M2 arrays using Pearson's correlation and Kolmogorov-Smirnov Test (K-S Test). A summary of the statistical analysis is tabulated in Table 1.
Table 1: Statistical Analysis for 7 December 2019 Storm Event

\begin{tabular}{|l|l|l|}
\hline Variables & \multicolumn{1}{|c|}{ Field-Model 1 } & \multicolumn{1}{|c|}{ Field-Model 2 } \\
\hline Inflow & Pearson 0.99 & Pearson 0.99 \\
& K-S Test: & K-S Test: \\
& D 0.02 < Critical D 0.61 & D 0.02 < Critical D 0.61 \\
\hline Outflow & Pearson 0.98 & Pearson 0.96 \\
& K-S Test: & K-S Test: \\
& D 0.05 < Critical D 0.61 & D 0.10 < Critical D 0.61 \\
\hline Water Level & Pearson 0.98 & Pearson 0.88 \\
& K-S Test: & K-S Test: \\
& D 0.10 < Critical D 0.61 & D 0.17 < Critical D 0.61 \\
\hline
\end{tabular}

The Pearson's correlation coefficient values are found high. On the other hand, the K-S Tests are meant for goodness of fit. M1 has shorter largest vertical distances (D) as highlighted in the table than M2 in terms of outflow and water level associated with the 7 December 2019 storm event.

Comparison of field and modelled hydrographs associated with 1 December 2019 storm event is presented in Figure 6.
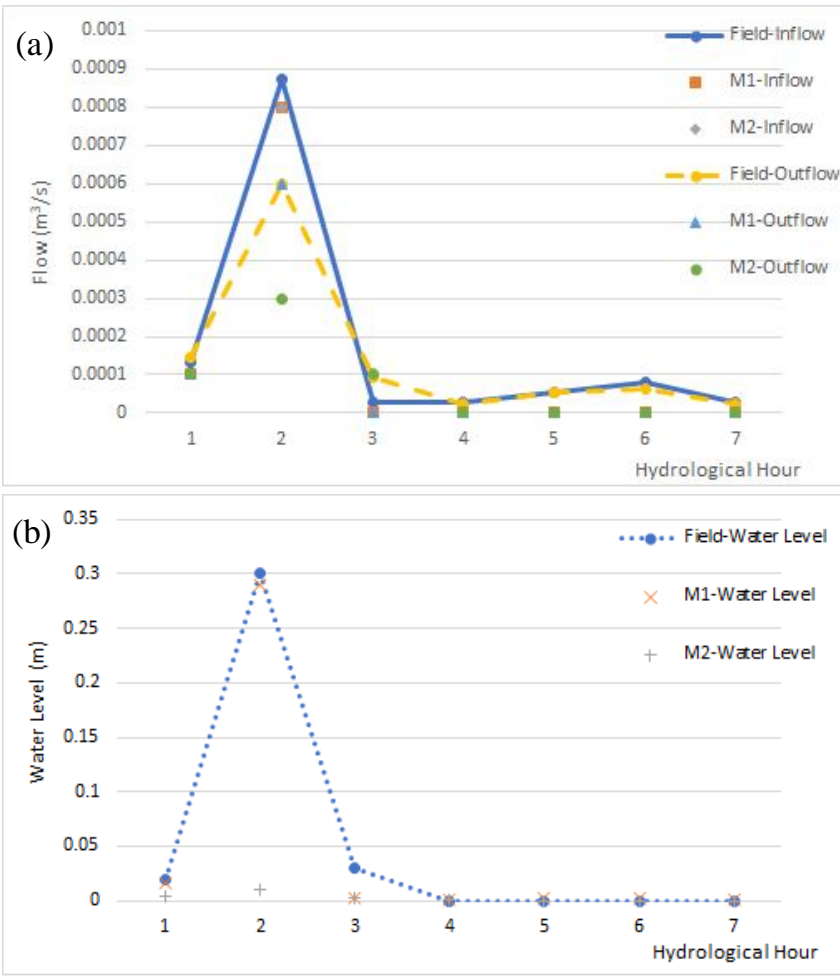

Figure 6: Simulation of StormPav System Subjected to 1 December 2019 Storm Event, a) Inflow and Outflow and b) Water Level Hydrographs

Similar to the previous simulation, the 7-hour plot of Field-M1 and Field-M2 arrays are compared with Pearson's correlation and K-S Test. A summary of the analysis is tabulated in Table 2 . 
Darrien Yau Seng Mah et al., International Journal of Emerging Trends in Engineering Research, 8(2), February 2020,344 - 349

Table 2: Statistical Analysis for 1 December 2019 Storm Event

\begin{tabular}{|l|l|l|}
\hline Variables & \multicolumn{1}{|c|}{ Field-Model 1 } & \multicolumn{1}{|c|}{ Field-Model 2 } \\
\hline Inflow & Pearson 0.99 & Pearson 0.98 \\
& K-S Test: & K-S Test: \\
& D 0.17 < Critical D 0.51 & D 0.15 < Critical D 0.51 \\
\hline Outflow & Pearson 0.99 & Pearson 0.96 \\
& K-S Test: & K-S Test: \\
& D 0.25 < Critical D 0.51 & D 0.16 < Critical D 0.51 \\
\hline Water Level & Pearson 0.99 & Pearson 0.96 \\
& K-S Test: & K-S Test: \\
& D 0.02 < Critical D 0.51 & D 0.11 < Critical D 0.51 \\
\hline
\end{tabular}

The Pearson's correlation coefficient values continue to be high. The K-S Tests show M2 has shorter D as highlighted in the table than M1 in terms of inflow and outflow, except for water level associated with the 1 December 2019 storm event.

Comparison of field and modelled hydrographs associated with $8 \& 9$ December 2019 storm event is presented in Figure 7.
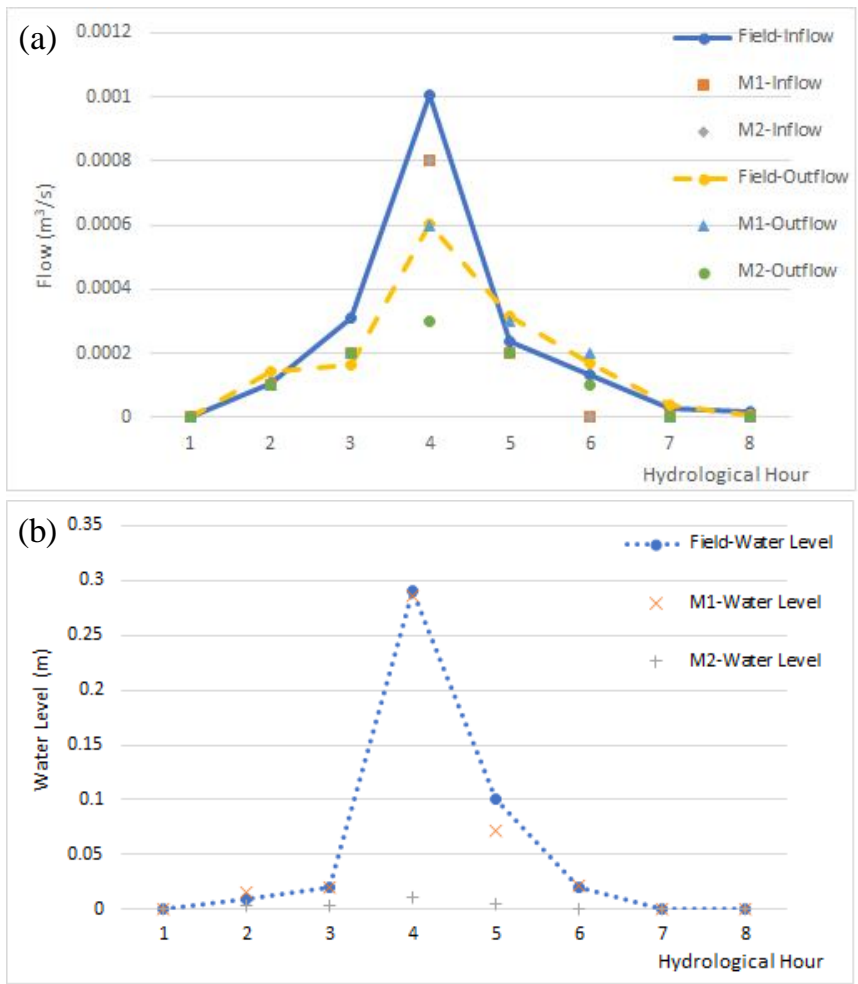

Figure 7: Simulation of StormPav System Subjected to 8\&9 December 2019 Storm Event, a) Inflow and Outflow and b) Water Level Hydrographs

The 8-hour plot of Field-M1 and Field-M2 arrays are compared with Pearson's correlation and K-S Test. A summary of the analysis is tabulated in Table 3.
Table 3: Statistical Analysis for 8\&9 December 2019 Storm Event

\begin{tabular}{|l|l|l|}
\hline Variables & \multicolumn{1}{|c|}{ Field-Model 1 } & \multicolumn{1}{|c|}{ Field-Model 2 } \\
\hline Inflow & Pearson 0.98 & Pearson 0.98 \\
& K-S Test: & K-S Test: \\
& D 0.09 < Critical D 0.48 & D 0.09 < Critical D 0.48 \\
\hline Outflow & Pearson 0.99 & Pearson 0.92 \\
& K-S Test: & K-S Test: \\
& D 0.03 < Critical D 0.48 & D 0.12 < Critical D 0.48 \\
\hline \multirow{2}{*}{ Water Level } & Pearson 0.99 & Pearson 0.90 \\
& K-S Test: & K-S Test: \\
& D 0.05 < Critical D 0.48 & D 0.29 < Critical D 0.48 \\
\hline
\end{tabular}

The Pearson's correlation coefficient values are also high. The K-S Tests show M1 has shorter D as highlighted in the table than M2 in terms of outflow and water level associated with the $8 \& 9$ December 2019 storm event.

Overall observations from Figure 5 to Figure 7, M2 is found to underestimate the outflows and water levels in the three presented cases, although the Pearson's correlation coefficient values range high between $0.88-0.96$. It makes sense considering that the field data is solely a detention system. The current field test setting does not reflect the flow routing along the "conduit" by kinematic wave in SWMM5.

M1 shows better visual match of field and modelled hydrographs from Figure 5 to Figure 7. K-S Test is used next to quantify the goodness of fit of its cumulative distribution of hydrographs. It is noted that Table 1 to Table 3 show Critical Ds are greater than Maximum Ds throughout the analysis. These indicate failure to reject null hypothesis $\left(\mathrm{H}_{0}\right.$ : The two samples are drawn from the same distribution).

We set aside whether the null hypothesis is true or not due to weak evidences to reject it. K-S Test has the advantage of measuring the degree of separation of a point between the cumulative distribution of field and modelled hydrographs. In another word, the shorter the largest vertical distance, the closer the two points matches. The outcomes point to M1 with the shorter largest vertical distances for two out of the three cases, namely the 7 December 2019 and 8\&9 December 2019 storm events.

Another point worth mentioning is that the inflow has better match than outflow and water level for both M1 and M2. The variables of outflow and water level are better predicted by M1 than M2.

\section{CONCLUSION}

The authors stated in the beginning of this paper that SWMM5 is not formulated to model compartmentalized stormwater detention system. Therefore, an exploration is attempted here by having a field test in a housing estate so that the collected field data are treated as control against assumed datasets. 
Darrien Yau Seng Mah et al., International Journal of Emerging Trends in Engineering Research, 8(2), February 2020,344 - 349

The first assumption considers the compartmentalized stormwater detention characteristics by applying the effective storage volume in a "storage unit" in SWMM5. The outcomes show the modelled hydrographs are closer match to the control. Hence, M1 is a better model for the characteristics.

The second assumption applies the effective storage volume in a conveying closed "conduit" in SWMM5. The outcomes show the modelled hydrographs are underestimated. This could be due to the current field test setting that have not incorporated conveying characteristics that the StormPav system could perform.

\section{APPENDIX}

Appendix A: 7 December 2019 (5-hour Storm Event)

\begin{tabular}{|c|c|c|c|c|}
\hline Time (hr) & Rainfal & \multicolumn{3}{|c|}{ Inflow $\left(\mathrm{m}^{3} / \mathrm{s}\right)$} \\
\cline { 3 - 5 } & $1(\mathrm{~mm})$ & Field & $\mathrm{M} 1$ & $\mathrm{M} 2$ \\
\hline $0100-0200$ & 6.5 & 0.000185 & 0.0002 & 0.0002 \\
\hline $0200-0300$ & 32.5 & 0.000924 & 0.0009 & 0.0009 \\
\hline $0300-0400$ & 8.1 & 0.000211 & 0.0002 & 0.0002 \\
\hline $0400-0500$ & 1.2 & 0.000013 & 0 & 0 \\
\hline $0500-0600$ & 0.2 & 0 & 0 & 0 \\
\hline
\end{tabular}

\begin{tabular}{|l|c|c|c|c|c|c|}
\hline \multirow{2}{*}{ Time (hr) } & \multicolumn{3}{|c|}{ Outflow $\left(\mathrm{m}^{3} / \mathrm{s}\right)$} & \multicolumn{3}{c|}{ Water Level (m) } \\
\cline { 2 - 7 } & Field & M1 & M2 & Field & M1 & M2 \\
\hline $\begin{array}{l}0100-020 \\
0\end{array}$ & $\begin{array}{c}0.00017 \\
2\end{array}$ & $\begin{array}{c}0.000 \\
1\end{array}$ & $\begin{array}{c}0.000 \\
1\end{array}$ & 0.01 & 0.02 & 0 \\
\hline $\begin{array}{l}0200-030 \\
0\end{array}$ & $\begin{array}{c}0.00063 \\
1\end{array}$ & $\begin{array}{c}0.000 \\
6\end{array}$ & $\begin{array}{c}0.000 \\
3\end{array}$ & 0.30 & 0.32 & 0.01 \\
\hline $\begin{array}{l}0300-040 \\
0\end{array}$ & $\begin{array}{c}0.00036 \\
7\end{array}$ & $\begin{array}{c}0.000 \\
4\end{array}$ & $\begin{array}{c}0.000 \\
2\end{array}$ & 0.13 & 0.10 & 0.01 \\
\hline $\begin{array}{l}0400-050 \\
0\end{array}$ & $\begin{array}{c}0.00004 \\
6\end{array}$ & 0 & $\begin{array}{c}0.000 \\
1\end{array}$ & 0.02 & 0.01 & 0 \\
\hline $\begin{array}{l}0500-060 \\
0\end{array}$ & $\begin{array}{c}0.00000 \\
8\end{array}$ & 0 & 0 & 0 & 0 & 0 \\
\hline
\end{tabular}

Appendix B: 1 December 2019 (7-hour Storm Event)

\begin{tabular}{|c|c|c|c|c|}
\hline Time (hr) & Rainfal & \multicolumn{3}{|c|}{ Inflow $\left(\mathrm{m}^{3} / \mathrm{s}\right)$} \\
\cline { 3 - 5 } & $1(\mathrm{~mm})$ & Field & M1 & M2 \\
\hline $0100-0200$ & 5.5 & 0.000132 & 0.0001 & 0.0001 \\
\hline $0200-0300$ & 29.5 & 0.000871 & 0.0008 & 0.0008 \\
\hline $0300-0400$ & 1.0 & 0.000026 & 0 & 0.0001 \\
\hline $0400-0500$ & 1.0 & 0.000026 & 0 & 0 \\
\hline $0500-0600$ & 2.0 & 0.000053 & 0 & 0 \\
\hline $0600-0700$ & 2.5 & 0.000079 & 0 & 0 \\
\hline $0700-0800$ & 1.0 & 0.000026 & 0 & 0 \\
\hline
\end{tabular}

\begin{tabular}{|l|c|c|c|c|c|c|}
\hline \multirow{2}{*}{ Time (hr) } & \multicolumn{3}{|c|}{ Outflow $\left(\mathrm{m}^{3} / \mathrm{s}\right)$} & \multicolumn{3}{c|}{ Water Level (m) } \\
\cline { 2 - 7 } & Field & M1 & M2 & Field & M1 & M2 \\
\hline $\begin{array}{l}0100-020 \\
0\end{array}$ & $\begin{array}{c}0.00014 \\
5\end{array}$ & $\begin{array}{c}0.000 \\
1\end{array}$ & $\begin{array}{c}0.000 \\
1\end{array}$ & 0.02 & 0.02 & 0 \\
\hline $\begin{array}{l}0200-030 \\
0\end{array}$ & $\begin{array}{c}0.00060 \\
0\end{array}$ & $\begin{array}{c}0.000 \\
6\end{array}$ & $\begin{array}{c}0.000 \\
3\end{array}$ & 0.30 & 0.29 & 0.01 \\
\hline $\begin{array}{l}0300-040 \\
0\end{array}$ & $\begin{array}{c}0.00009 \\
2\end{array}$ & 0 & $\begin{array}{c}0.000 \\
1\end{array}$ & 0.03 & 0 & 0 \\
\hline $\begin{array}{l}0400-050 \\
0\end{array}$ & $\begin{array}{c}0.00002 \\
4\end{array}$ & 0 & 0 & 0 & 0 & 0 \\
\hline $\begin{array}{l}0500-060 \\
0\end{array}$ & $\begin{array}{c}0.00005 \\
3\end{array}$ & 0 & 0 & 0 & 0 & 0 \\
\hline
\end{tabular}

\begin{tabular}{|l|c|c|c|c|c|c|}
\hline $\begin{array}{l}0600-070 \\
0\end{array}$ & $\begin{array}{c}0.00006 \\
1\end{array}$ & 0 & 0 & 0 & 0 & 0 \\
\hline $\begin{array}{l}0700-080 \\
0\end{array}$ & $\begin{array}{c}0.00002 \\
4\end{array}$ & 0 & 0 & 0 & 0 & 0 \\
\hline
\end{tabular}

Appendix C: 8\&9 December 2019 (8-hour Storm Event)

\begin{tabular}{|c|c|c|c|c|}
\hline Time (hr) & Rainfal & \multicolumn{3}{|c|}{ Inflow $\left(\mathrm{m}^{3} / \mathrm{s}\right)$} \\
\cline { 3 - 5 } & $1(\mathrm{~mm})$ & Field & $\mathrm{M} 1$ & $\mathrm{M} 2$ \\
\hline $2100-2200$ & 0.5 & 0 & 0 & 0 \\
\hline $2200-2300$ & 5.4 & 0.000106 & 0.0001 & 0.0001 \\
\hline $2300-0000$ & 6.2 & 0.000311 & 0.0002 & 0.0002 \\
\hline $0000-0100$ & 29.0 & 0.001003 & 0.0008 & 0.0008 \\
\hline $0100-0200$ & 8.6 & 0.000238 & 0.0002 & 0.0002 \\
\hline $0200-0300$ & 6.3 & 0.000132 & 0 & 0 \\
\hline $0300-0400$ & 1.2 & 0.000026 & 0 & 0 \\
\hline $0400-0500$ & 0.6 & 0.000016 & 0 & 0 \\
\hline
\end{tabular}

\begin{tabular}{|l|c|c|c|c|c|c|}
\hline \multirow{2}{*}{ Time (hr) } & \multicolumn{3}{|c|}{ Outflow $\left(\mathrm{m}^{3} / \mathrm{s}\right)$} & \multicolumn{3}{c|}{ Water Level (m) } \\
\cline { 2 - 7 } & Field & $\mathrm{M} 1$ & $\mathrm{M} 2$ & Field & $\mathrm{M} 1$ & $\mathrm{M} 2$ \\
\hline $\begin{array}{l}2100-220 \\
0\end{array}$ & $\begin{array}{c}0.00000 \\
3\end{array}$ & 0 & 0 & 0 & 0 & 0 \\
\hline $\begin{array}{l}2200-230 \\
0\end{array}$ & $\begin{array}{c}0.00014 \\
2\end{array}$ & $\begin{array}{c}0.000 \\
1\end{array}$ & $\begin{array}{c}0.000 \\
1\end{array}$ & 0.01 & 0.01 & 0 \\
\hline $\begin{array}{l}2300-000 \\
0\end{array}$ & $\begin{array}{c}0.00016 \\
4\end{array}$ & $\begin{array}{c}0.000 \\
2\end{array}$ & $\begin{array}{c}0.000 \\
2\end{array}$ & 0.02 & 0.02 & 0 \\
\hline $\begin{array}{l}0000-010 \\
0\end{array}$ & $\begin{array}{c}0.00060 \\
2\end{array}$ & $\begin{array}{c}0.000 \\
6\end{array}$ & $\begin{array}{c}0.000 \\
3\end{array}$ & 0.29 & 0.29 & 0.01 \\
\hline $\begin{array}{l}0100-020 \\
0\end{array}$ & $\begin{array}{c}0.00031 \\
4\end{array}$ & $\begin{array}{c}0.000 \\
3\end{array}$ & $\begin{array}{c}0.000 \\
2\end{array}$ & 0.10 & 0.07 & 0 \\
\hline $\begin{array}{l}0200-030 \\
0\end{array}$ & $\begin{array}{c}0.00016 \\
7\end{array}$ & $\begin{array}{c}0.000 \\
2\end{array}$ & $\begin{array}{c}0.000 \\
1\end{array}$ & 0.02 & 0.02 & 0 \\
\hline $\begin{array}{l}0300-040 \\
0\end{array}$ & $\begin{array}{c}0.00003 \\
8\end{array}$ & 0 & 0 & 0 & 0 & 0 \\
\hline $\begin{array}{l}0400-050 \\
0\end{array}$ & \begin{tabular}{c}
0.00001 \\
\hline
\end{tabular}
\end{tabular}

Note: M1=SWMM5 storage unit; M2=SWMM5 Conduit

\section{ACKNOWLEDGEMENT}

The authors would like to acknowledge Universiti Malaysia Sarawak for financing this research through the Post-Graduate Research Grant Scheme (Grant No F02/PGRG/1911/2019).

\section{REFERENCES}

1. U. Kuruppu, A. Rahman, and M. A. Rahman. Permeable pavement as a stormwater best management practice: a review and discussion, Environmental Earth Sciences, 78:327, doi:10.1007/s12665-019-8312-2, May 2019.

2. A. Awad, F. A. Bajari, and F. A. Adday. A case study on rainwater harvesting and reuse in Jordan, International Journal of Emerging Trends in Engineering Research, Vol. 7, No. 11, pp. 398-402, November 2019. https://doi.org/10.30534/ijeter/2019/017112019 
3. SVC. MC2 Multi-Cell Detention Device, Available from http://svc.com.au (Accessed on 16 January 2020), July 2017.

4. Humes. Stormwater Harvesting and Reuse, Available from http://humeswatersolutions.com.au (Accessed on 18 January 2020), September 2012.

5. M. A. Mannan, Y. S. Mah, N. Bateni, D. C. L. Teo, F. J. Putuhena, R. A. Bustami, W. H. W. Ibrahim, C. L. F. Lee, and H. L. Lim. System and Method for Pavement, Patent Registration No PI2016704420, Malaysian Intellectual Property Corporation, 2016.

6. L. A. Rossman, R. E. Dickinson, T. Schade, C. C. Chan, E. Burgess, D. Sullivan, F.-H. Lai. SWMM5 - the next generation of EPA's Storm Water Management Model, Journal of Water Management Modelling, Article R220-16, 2004.

7. D. Y. S. Mah, J. O. K. Ngu, V. Liew, W. H. W. Ibrahim. Augmenting drainage system in the old town of Kuching, Sarawak, Malaysia, International Journal of Engineering and Technology, Vol. 7, No. 3.8, pp. 36-39, 2018. https://doi.org/10.14419/ijet.v7i3.18.16669

8. J. O. K. Ngu, D. Y. S. Mah, C. V. Liow, and I. T. Ngu. Modelling of on-site stormwater detention underneath a car porch, International Journal of Innovative Technology and Exploring Engineering, Vol. 8, Issue 12, pp. 4304-4307, October 2019.

9. C. V. Liow, D. Y. S. Mah, M. R. R. bin Mohd Arif Zainol. Modelling of StormPav Green Pavement: Inlet and outlet of integrated permeable road and stormwater detention system, International Journal of Civil Engineering and Technology, Vol. 10, Issue 2, pp. 966-976, February 2019.

10. C. V. Liow, D. Y. S. Mah, and M. R. R. bin Mohd Arif Zainol. Modelling of StormPav Green Pavement System with Storm Water Management Model and InfoWorks Collection System, International Journal of Recent Technology and Engineering, Vol. 8, Issue 2, pp. 1449-1452, July 2019.

https://doi.org/10.35940/ijrte.B2158.078219

11. C. V. Liow, D. Y. S. Mah, and M. A. Malek. Modelling of StormPav Green Pavement System using Storm Water Management Model and SolidWorks Flow Simulation, International Journal of Recent Technology and Engineering, Vol. 8, Issue 2, pp. 4673-4679, July 2019.

https://doi.org/10.35940/ijrte.B3495.078219 